\title{
ESTIMATION OF THE CHEMICAL CONTENT OF THE SYRIAN TRUFFLES (Tuber brumale vittadini) AND STUDY THEIR EFFECT ON SOME BLOOD PARAMETERS AND SOME ORGANS OF THE DIABETIC SWISS ALBINO MICE Al abbad, Najat A.* and Eman A. Moussa** \\ * Nutrition and Food Sci. Dept., Fac. Agric. and Food Sci., King Faisal Univ., Al Hassa, Saudi Arabia. \\ ** Zoology Dept., Fac. Sci., Kafrelsheikh Univ., Kafrelsheikh, Egypt
}

\begin{abstract}
The present study will give us deeper insights on the Syrian truffles which are one of the miracle of nature. Some components of Syrian truffle (Tuber brumale vittadini) were estimated in terms of nutritional value. The effects of Syrian truffle (ST) on the normal and onset of alloxan-induced diabetes in male Swiss albino mice were examined. It was observed that the mouse given orally extract of ST (10 ppm for 12 weeks) showed a significant decrease in the blood glucose level and glycosylated hemoglobin A1c of diabetic mice induced by intra-peritoneal injection of alloxan (50 $\mathrm{mg} / \mathrm{kg}$, i.p.) and significantly improved the glucose tolerance test. Tuber brumale vittadini may normalize blood AST, ALT, creatinine and cholesterol in alloxan induceddiabetic group. Histolochemical examinations were also done on liver and kidney. Oral administration of 10 ppm ST extract,3 times weekly for 12 weeks of alloxan diabetic mice showed decrease in collagen fibers in liver and kidney tissues and increase in liver glycogen content whereas decreased glycogen in the kidney as compared with the control group. These findings revealed that extract of ST may have a potential benefit in the treatment of diabetes, play a role in its modulating hepatic and renal structural changes in diabetic Swiss albino mice and may reduces the risk of diabetic complications.
\end{abstract}

Keywords:- Syrian tuber, Tuber brumale vittadini,Hyperglycemia, Diabetes Mellitus and mice.

\section{INTRODUCTION}

Truffles are the hypogenous fruiting bodies of Ascomycete fungi that live in symbiosis with roots of trees such as oaks, hazels, poplar (Harley and Smith, 1983) and some shrubs as Cistus (Fontana and Giovannetti 1979). Ectomycorrhizas develop Truffles belong to the genus Tuber. Earlier included in the order Tuberales, including hypogenous ascomycetes, they were reclassified in the order Pezizales following phylogenetic studies (O'Donnell et al., 1997). Truffles also known as "black diamonds" have been highly praised in the last 50 years because of their rarity and their complex aroma. There are more than 60 different kinds of truffles around the world (Hawksworth et al., 1995). Truffles are thought to be a "miracle of nature" and have been since ancient times the ultimate in gastronomy because of their highly nutritional attributes. Recent studies have proven that some truffles contain ergosteroids, and ergosterol, the most widespread fungal sterol, and brassicasterol (Gao et al., 2001a; Harki et al., 1996) as well as volatile organic compounds in truffle aroma which is characteristically sulfurous (Zeppa et al., 2004; Menotta et al., 2004; Diaz et al., 2002, 2003). 
A truffle is a fungal fruiting body that develops underground and relies on mycophagy for spore dispersal. Almost all truffles are ectomycorrhizal and are therefore usually found in close association with trees.

There are hundreds of species of truffles, but the fruiting body of some (mostly in the genus Tuber) are highly prized as a food. Famed 18th century French gastronome Brillat-Savarin called these truffles "the diamond of the kitchen". Edible truffles are held in high esteem in French, Spanish, northern Italian and Croatian cooking, as well as in international haute cuisine. Tuber species are some of the most highly valued truffles, both gastronomically and economically (Hall \& Yun 2002, Olivier et al. 1996). Some edible truffles have great food, health and economic, and have edible flavor with a distinct smell (Mandeel and Al-laith, 2007; Ammarellou, 2007).

Diabetes mellitus (DM) is a group of metabolic disorders that result in hyperglycemia as a result of a relative or absolute lack of insulin, or the actions of insulin on its target tissues or both (Srividya and Shailendra, 2008). Insulin deficiency in turn leads to chronic hyperglycemia with disturbances of carbohydrate, fat and protein metabolism. Diabetes is currently the seventh leading cause of death in the developed world. It is the most common endocrine disorder and by the year 2010, it is estimated that more than 200 million people worldwide will have DM and 300 million will subsequently have the disease by 2025 (Bastaki, 2005). Diabetes is a worldwide chronic disease with variable prevalence. In adult-onset diabetes so called type 2 or non-insulin-dependent diabetes mellitus (NIDDM), the pancreas often makes enough insulin, but the body cells don't efficiently respond to the insulin. People with diabetes cannot properly process glucose, the main fuel body uses for energy. As a result, glucose stays in the blood, causing blood glucose to rise. At the same time, however, the cells of the body starve for glucose. Insulin is the mainstay for patients with type 1 diabetes and it is also important in type 2 when blood glucose levels cannot be controlled by diet, weight loss, exercise and oral medications. Previous to the use of insulin, dietary measures were the major form of this treatment especially in many developing countries; this includes the traditional medicines derived from plants (Ayyanar, et al. 2008). Also the high cost of diabetes, both in healthcare and quality of life, has led to a growing interest in alternative therapies for diabetes management. Several botanical supplements have been studied as potential therapeutic agents in the management of diabetes and its related complications.

Medicinal plants used to treat diabetic conditions are of considerable interest and a number of plants have shown varying degrees of hypoglycemic and anti-hyperglycemic activity.

It is important to highlight that the most characteristic compounds of Tuber spp. are dimethylsulfide, 2-methylpropanal, 2-methylbutanal, 3 methylbutanal, 2-methyl-1-propanol, 2-methyl-1-butanol and 3-methyl-1butanol. Dimethylsulfide has been described as responsible for the detection of such fungi by dogs and flies (Talou, et al., 1990 and Daniel and Habener 2002), and it might also have an antioxidant action (Sunda, et al, 2002). Moreover, dimethylsulfide produces the Tuber spp. Tyrosinase reversible inhibition; this enzyme is involved in truffle development and differentiation 
(Zarivi et al., 2003). Klandorf et al.,(1989) concluded that when Dimethyl sulfoxide was fed to female Non-obese onset diabetic mice on a purified AIN76 diet, diabetes was reduced to $36 \%$.

Glycosylated(or glycated) hemoglobin, measured as $\mathrm{HbA} 1 \mathrm{c}$ is used as an index of mean glycemia in diabetes over the preceding two to three months i.e.life span of erythrocyte (Schwartz, 1995 and Thevarajah, et al. 2009). The percentage of glycosylated hemoglobin in human blood depends on the concentration of glucose, the duration of glucose exposure to hemoglobin and the turnover of erythrocytes. Measuring glycated hemoglobin assesses the effectiveness of therapy by monitoring long-term serum glucose regulation (Larsen et al.,1990). The American Diabetes Association (ADA, 2008) recommends keeping the HbA1c less than $7 \%$. The ADA,(2008) reported that there is a $10 \%$ decrease in relative risk of microvascular complications, such as diabetic nephropathy or diabetic neuropathy, for every $1 \%$ reduction in $\mathrm{HbA} 1 \mathrm{C}$.

The present work aimed to identify some components of the chemical content in terms of nutritional value of the Syrian truffles (Tuber brumale vittadini) and to study the possible hypoglycemic effect of its extract as a natural and safe anti-diabetic agent for normal and diabetic mice previously treated with alloxan by measuring the blood glucose levels, some blood parameters related to diabetes, glucose tolerance test, glycosylated HbA1c and histochemical study on the liver and kidney tissue for detecting glycogen and collagen fibers.

\section{MATERIALS AND METHODS}

\section{Estimation of some components of the Chemical Content of the Syrian Truffle}

Some components of Syrian truffle were estimated in terms of nutritional value according to standard methods of AOAC, 1995 in the IDAC Laboratories Riyadh, Saudi Arabia.

Preparation of Syrian truffls extract

Syrian truffles (ST) or Tuber brumale vittadini are characterized by a dark brown peridium of 4-6 cornered, flat, closely adjacent pyramidal warts (Fig.1). Syrian truffles were obtained from Syrian local market, truffles been crushed by the mill mixer Braun (Germany), and its extract was prepared using boiled distilled water. The clear extract was stored at $4^{\circ} \mathrm{C}$.

\section{Animals:}

40 male Swiss albino mice ( 3 months old, $25-30 \mathrm{~g}$ ) were obtained from an inbred strain in the College of Veterinary Medicine, King Faisal University, Al-Hassa, Saudi Arabia. Mice were housed separately in stainless steel cages containing hard wood chips, five animals /cage. Mice were housed at room temperature $\left(20-22 \mathrm{C}^{\circ}\right)$.

Animals in all groups were given a basal diet composed of $60 \%$ of ground corn meal, $15 \%$ ground beans, $10 \%$ wheat bran, $10 \%$ corn oil, $3 \%$ casein, $1 \%$ mineral mixture, and $1 \%$ vitamin mixture (Nelson and Halberg, 1986). Water was given ad libitum. 


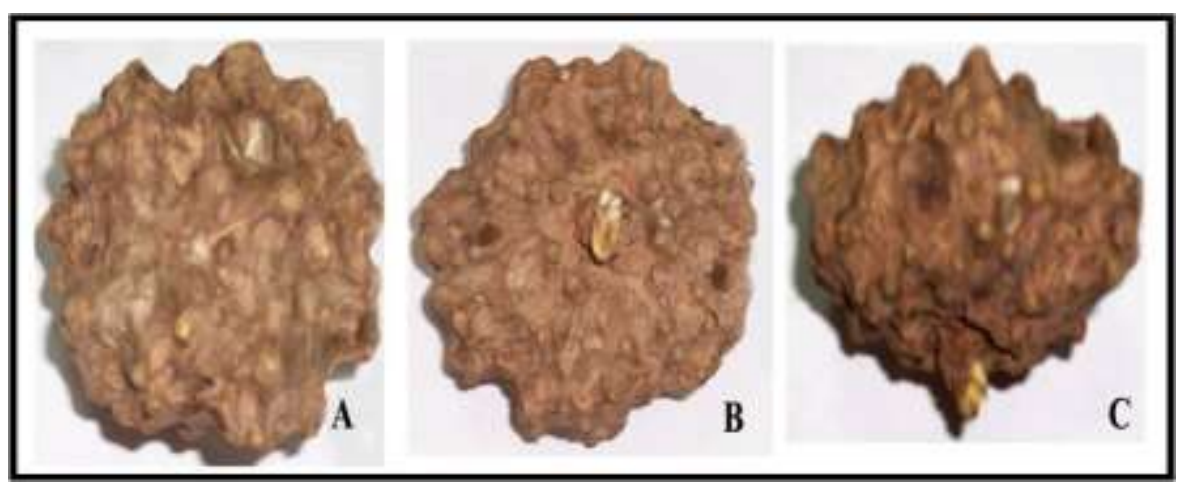

Figure (1): showing Syrian truffle, Tuber bromale vittadini: A- surface view $B$ - bottom view and $C$ - lateral view. $X$ : natural size.

Induction of experimental diabetes (control diabetic group):

Each animal in this group (10 males) was injected intraperitoneally with a single dose of $50 \mathrm{mg} / \mathrm{kg} \mathrm{b}$. wt. of alloxan (Takeshi et al., 1998; AlerconAguilar et al., 2000 and Shenoy, 2000). Alloxan (C4 H2 N2 O4) also named 2,4,5,6 $(1 \mathrm{H}, 3 \mathrm{H})$-Pyrimidinetetrone. Random plasma glucose levels were measured to ascertain the diabetic status in different groups of mice.

\section{Experimental Design:}

Animals were divided into 4 groups (10 males for each).

Group 1 was used as control mice (without alloxan \& without ST).

Group 2 was used as control diabetic mice (alloxan without ST).

Group 3 was used as control ST (without alloxan with ST).

Group 4 was used as treated diabetic mice with ST (alloxan and ST).

Distilled water was used as a negative control for group 1 and 2, control ST and diabetic groups were administrated orally 3 times weekly $10 \mathrm{ppm}$, for a period of 3 months for groups 3 and 4 .

Mice were sacrificed at the end of three months to remove liver and kidney for histochemical study.

\section{Hematological studies:}

Blood collection using the saphenous puncture (Hem et al., 1998) for blood sampling of the mouse (superficial veins of the hind limb). As a general rule, a blood volume equivalent to about $0.5 \%$ of the animal's body weight may be safely drawn, as a single sample (Wolfensohn and Lloyd 1994), and this can usually be repeated at fortnightly intervals without disturbances to the animal's hematological status. Fasting blood (12 hours) was collected from 5 males weekly from each group for estimation of glucose and blood parameters.

\section{Determination of blood parameters:}

Blood glucose levels and other blood parameters were determined using a dry chemistry blood analyzer (Reflotron plus, Roche, Germany) using Reflotron kites (Roche, Diagnostic GmbH D 1964224001 Mannheim, Germany) (James et al., 1988; Phillips et al., 1988 and Wadaan,2006) and hemoglobin A1C meter (NycoCard® Reader II, Oslo, Norway) (Jeppsson et 
al., 2002). Glucose tolerance test was carried out using method of Fischbach and Dunning (2004).

Preparation of histochemical slides:

Mice were observed regularly throughout the experiment. Any moribund or dead animals were removed and autopsied. All organs were examined, and tumours or other pathological changes were collected. The liver and kidney were fixed in $1 \%$ neutral buffered formalin followed by processing in the routine technique of paraffin embedding and blocking. Paraffin sections of 4-6 micrometers thick were prepared by microtome and then routinely stained with Masson's Trichrome Stain (MTS) for detecting collagen fibers (Bancroft \& Stevens, 1990) and Periodic acid-Schiff Stain (PAS) for detecting Polysaccharides and glycogen (Pearse, 1985) and examined on light microscope for the histochemical studies.

Statistical Analysis:

All observations were first recorded in a notebook and entered into PC computer and verified by another person for accuracy of data entry. Values were expressed as mean \pm SD (of 10 animals). The statistical analysis was performed using a Student T-test (two tailed) software program according to Flower and Cohen, (1997). P values of less than 0.05 were considered statistically significant.

\section{RESULTS}

In this study we measured some components of the chemical content of the Syrian truffles (Tuber brumale vittadini) in terms of nutritional value, according to standered method of measuring AOAC, 1995. This estimation revealed that, truffle have high nutritional value especially for diabetus, scince having low suger contents and high value of vitamins and minerals as showen in table (1).

The blood glucose levels are recorded in table (2). The blood glucose levels (BGLs) of diabetic mice treated with ST extract were reduced in comparison with those control diabetic group. Fasting BGLs (12 hours) were lowered significantly $(p<0.05)$ after giving $10 \mathrm{ppm}$ of ST extract 3 times weekly for 12 weeks. Also results indicate that St improved postpradinal blood glucose level as ST caused a significant decrease $(P<0.05)$ in the blood glucose level at the end of the experiment as compared to control diabetic group.

Oral administration of $10 \mathrm{ppm}$ of ST extract 3 times weekly for a period of 12 weeks significantly improved the performance of alloxan diabetic mice in the glucose tolerance test (Table 3 ) and significantly decreased Hemoglobin A1c ratio (Table 4).

Tuber brumale vittadini extract caused a significant decrease of serum or plasma AST (Aspartate aminotransferase), ALT (Alanineaminotransferase), creatinine and total cholesterol levels in the blood (Table 4). Also, these results suggested that ST possesses anti-diabetic effect in alloxan-induced diabetic mice. 
Table (1): Chemical content in terms of nutritional value of the Syrian truffle (Tuber brumale vittadi):

\begin{tabular}{|c|c|}
\hline Content & Quantity \\
\hline Moisture (\%) & 9.35 \\
\hline Crude Protein (\%) & 6.01 \\
\hline Ether Extract (\%) & 0.80 \\
\hline Ash (\%) & 3.48 \\
\hline Crude Fiber (\%) & 6.92 \\
\hline Calcium (\%) & 0.88 \\
\hline Phosphorus (\%) & 0.14 \\
\hline Sodium (\%) & 0.023 \\
\hline Potassium (\%) & 0.61 \\
\hline Magnesium (\%) & 0.11 \\
\hline Copper $(\mathrm{mg} / \mathrm{kg})$ & 2.72 \\
\hline Iron $(\mathrm{mg} / \mathrm{kg})$ & 130 \\
\hline Manganese $(\mathrm{mg} / \mathrm{kg})$ & 10.22 \\
\hline Zinc $(\mathrm{mg} / \mathrm{kg})$ & 23.31 \\
\hline V. A (IU / g) & 1.18 \\
\hline V. E $(\mathrm{mg} / \mathrm{kg})$ & 264.4 \\
\hline V. D $(\mathrm{IU} / \mathrm{g})$ & 059 \\
\hline V. C (mg / kg) & 26.10 \\
\hline V. B1 $(\mathrm{mg} / \mathrm{kg})$ & 10.10 \\
\hline V.B2 (mg / kg) & 8.40 \\
\hline V. B6 (mg / kg) & 9.10 \\
\hline $\operatorname{Niacin}(\mathrm{mg} / \mathrm{kg})$ & 74.70 \\
\hline Folic Acid (mg / kg) & 6.50 \\
\hline Reducing Sugar (\%) & 2.90 \\
\hline Sucrose (\%) & 0.19 \\
\hline Glucose (\%) & 0.27 \\
\hline Fructose (\%) & 0.98 \\
\hline Totale Sugar (\%) & 1.44 \\
\hline
\end{tabular}

(\%) : percentage ratio

(IU / g) : International Units per gram

(mg / kg) : milligram per kilogram

Table (2): Effect of Syrian truffle (Tuber brumale vittadini) extract on the blood glucose level in normal and alloxan diabetic mice among 12 weeks.

\begin{tabular}{|c|c|c|c|c|c|c|c|}
\hline Groups & $1 w$ & $2 w$ & $4 w$ & $6 w$ & $8 w$ & $10 w$ & $12 \mathrm{w}$ \\
\hline $\begin{array}{l}\text { 1-Control mice group } \\
12 \text { h Fasting blood glucose level (mg/dl) }\end{array}$ & $\begin{array}{c}95 \pm \\
12\end{array}$ & $\begin{array}{c}101 \pm \\
6.2\end{array}$ & $\begin{array}{l}97 \pm \\
9.3\end{array}$ & $\begin{array}{c}105 \pm \\
8.4\end{array}$ & $\begin{array}{r}95 \pm \\
9.8\end{array}$ & $\begin{array}{c}107 \pm \\
6.6\end{array}$ & $\begin{array}{c}102 \pm \\
5.5\end{array}$ \\
\hline $\begin{array}{l}\text { 2h Postprandial blood glucose level } \\
(\mathrm{mg} / \mathrm{dl})\end{array}$ & $\begin{array}{c}105 \pm \\
8.2 \\
\end{array}$ & $\begin{array}{c}109 \pm \\
9.6\end{array}$ & $\begin{array}{c}101 \pm \\
9.9\end{array}$ & $\begin{array}{c}116 \pm \\
7.3\end{array}$ & $\begin{array}{l}108 \pm \\
9.5\end{array}$ & $\begin{array}{c}112 \pm \\
6.9\end{array}$ & $\begin{array}{l}114 \pm \\
9.5\end{array}$ \\
\hline $\begin{array}{l}\text { 2- Control ST extract group } \\
12 \text { h Fasting blood glucose level (mg/dl) }\end{array}$ & $\begin{array}{r}92 \pm \\
8.3\end{array}$ & $\begin{array}{l}99 \pm \\
9.8\end{array}$ & $\begin{array}{l}97 \pm \\
11.2\end{array}$ & $\begin{array}{l}89 \pm \\
16.4\end{array}$ & $\begin{array}{l}95 \pm \\
14.1\end{array}$ & $\begin{array}{c}100 \pm \\
6.9\end{array}$ & $\begin{array}{l}96 \pm \\
8.7\end{array}$ \\
\hline $\begin{array}{l}\text { 2h Postprandial blood glucose level } \\
(\mathrm{mg} / \mathrm{dl})\end{array}$ & $\begin{array}{l}107 \pm \\
14.4\end{array}$ & $\begin{array}{l}114 \pm \\
23.5\end{array}$ & $\begin{array}{c}101 \pm \\
9.8\end{array}$ & $\begin{array}{l}106 \pm \\
12.9\end{array}$ & $\begin{array}{l}104 \pm \\
10.8\end{array}$ & $\begin{array}{l}110 \pm \\
15.7\end{array}$ & $\begin{array}{l}101 \pm \\
11.4\end{array}$ \\
\hline $\begin{array}{l}\text { 3- Control diabetic group } \\
12 \text { h Fasting blood glucose level(mg/dl) }\end{array}$ & $\begin{array}{l}238 \pm \\
16.9\end{array}$ & $\begin{array}{l}249 \pm \\
11.4\end{array}$ & $\begin{array}{l}241 \pm \\
18.5\end{array}$ & $\begin{array}{l}231 \pm \\
19.6\end{array}$ & $\begin{array}{c}251 \pm \\
16\end{array}$ & $\begin{array}{l}246 \pm \\
23.7\end{array}$ & $\begin{array}{l}255 \pm \\
14.2\end{array}$ \\
\hline $\begin{array}{l}\text { 2h Postprandial blood glucose level } \\
(\mathrm{mg} / \mathrm{dl})\end{array}$ & $\begin{array}{l}322 \pm \\
15.3\end{array}$ & $\begin{array}{l}334 \pm \\
18.6\end{array}$ & $\begin{array}{l}337 \pm \\
17.6\end{array}$ & $\begin{array}{l}342 \pm \\
21.4\end{array}$ & $\begin{array}{l}361 \pm \\
14.8\end{array}$ & $\begin{array}{l}338 \pm \\
17.8\end{array}$ & $\begin{array}{l}354 \pm \\
10.5\end{array}$ \\
\hline $\begin{array}{l}\text { 4- ST extract- diabetic group } \\
12 \text { h Fasting blood glucose level(mg/dl) }\end{array}$ & $\begin{array}{l}229 \pm \\
20.4\end{array}$ & $\begin{array}{l}236 \pm \\
17.7\end{array}$ & $\begin{array}{l}218 \pm \\
12.4\end{array}$ & $\begin{array}{l}210 \pm \\
19.5\end{array}$ & $\begin{array}{l}199 \pm \\
13.8\end{array}$ & $\begin{array}{l}193 \pm \\
16.9\end{array}$ & $\begin{array}{c}187^{*} \pm \\
13.6\end{array}$ \\
\hline $\begin{array}{l}\begin{array}{l}2 \mathrm{~h} \text { Postprandial blood glucose level } \\
(\mathrm{mg} / \mathrm{dl})\end{array} \\
\end{array}$ & $\begin{array}{l}304 \pm \\
12.3\end{array}$ & $\begin{array}{l}299 \pm \\
17.6\end{array}$ & $\begin{array}{l}290 \pm \\
13.9\end{array}$ & $\begin{array}{c}276^{*} \pm \\
12.6\end{array}$ & $\begin{array}{r}280^{*} \\
\pm 14.8 \\
\end{array}$ & $\begin{array}{c}271^{*} \pm \\
16.5\end{array}$ & $\begin{aligned} 255^{*} \\
\pm 19.8 \\
\end{aligned}$ \\
\hline
\end{tabular}

The data represent the mean \pm SD of 10 animals.

* $P<0.05$ as compared with the corresponding value of the control diabetic group. 
Table (3): Effect of treatment with Syrian truffle extract (10 ppm 3 times weekly for 12 weeks) on blood glucose levels $(\mathrm{mg} / \mathrm{dl})$ in alloxan diabetic mice during glucose tolerance test.

\begin{tabular}{|l|c|c|}
\hline Time (minutes) & Pre-treatment $^{\star}(\mathbf{m g} / \mathbf{d l})$ & Post-treatment $^{\star \star}(\mathbf{m g} / \mathbf{d l})$ \\
\hline 30 & $285 \pm 11.4$ & $203 \pm 13.7$ \\
\hline 60 & $396 \pm 20.1$ & $240 \pm 9.4$ \\
\hline 120 & $434 \pm 18.6$ & $300 \pm 16.3$ \\
\hline
\end{tabular}

The data represent the mean \pm SD of 10 animals.

* Blood glucose level before the initiation of treatment with ST extract

** Blood glucose level after treating 12 weeks with ST extract

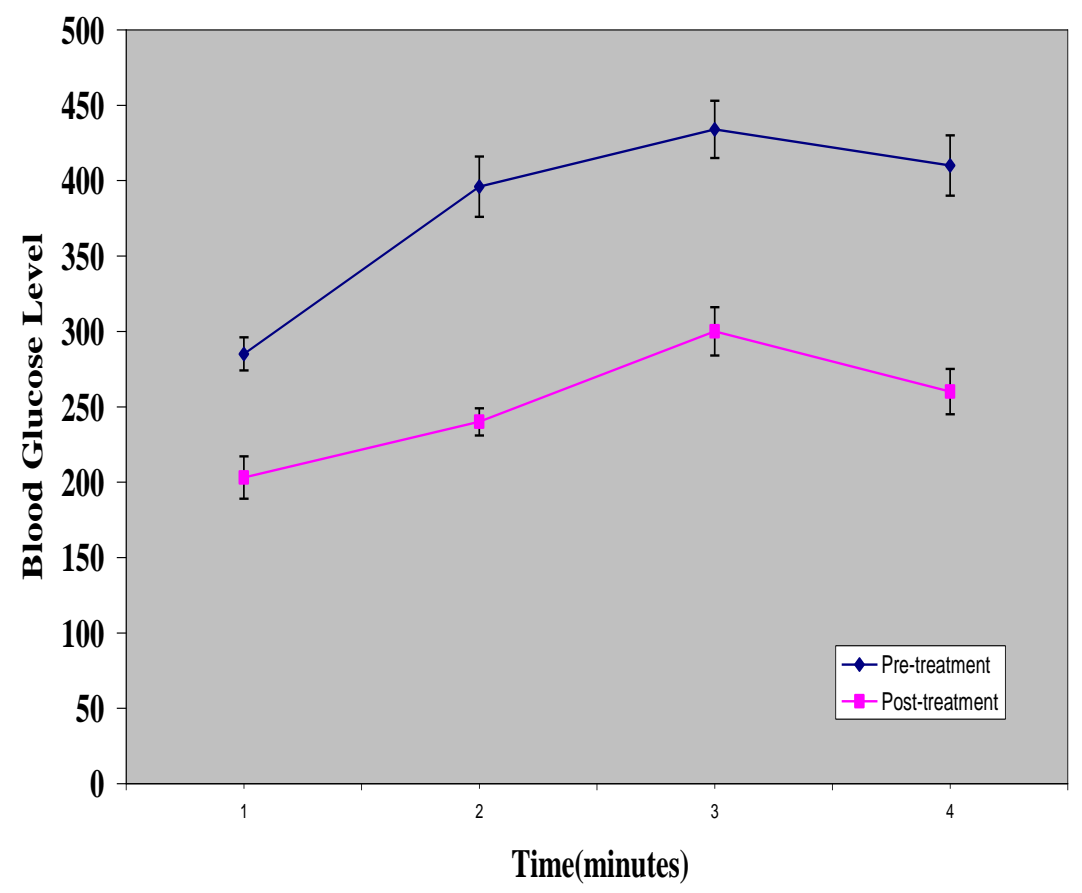

Figure (2): Effect of Treatment with Syrian truffle extracts 10 ppm for 12 weeks on Blood Glucose level in alloxan diabetic mice during glucose tolerance test. 
Table (4): Effect of Syrian truffle (Tuber brumale vittadini) extract on some blood parameters in normal and alloxan diabetic mice among 12 weeks.

\begin{tabular}{|c|c|c|c|c|c|}
\hline Groups & $\begin{array}{l}\text { AST } \\
\text { IU॰/I }\end{array}$ & $\begin{array}{l}\text { ALT } \\
\text { IU॰/I }\end{array}$ & $\begin{array}{c}\text { Creatinin } \\
\mu \mathrm{mol} / \mathrm{l}\end{array}$ & $\begin{array}{c}\text { Cholestrol } \\
\text { mmol/l }\end{array}$ & $\begin{array}{l}\text { Hb A1c** } \\
\mathrm{mmol} / \mathrm{I}\end{array}$ \\
\hline $\begin{array}{l}\text { 1-Control mice group } \\
\text { 1week }\end{array}$ & $99.7 \pm 18$ & $44.3 \pm 14$ & $45.1 \pm 11$ & $2.9 \pm 0.5$ & $5.3 \pm 0.6$ \\
\hline After 12 week & $95.1 \pm 13$ & $44.8 \pm 7.6$ & $47.3 \pm 6.1$ & $2.8 \pm 0.2$ & $5.5 \pm 0.6$ \\
\hline $\begin{array}{l}\text { 2-Control ST extract group } \\
\text { 1week }\end{array}$ & $96.8 \pm 7.1$ & $44.2 \pm 1.4$ & $42.3 \pm 0.5$ & $2.7 \pm 0.9$ & $5.1 \pm 0.9$ \\
\hline After 12 week & $89.7 \pm 5.8$ & $43.5 \pm 0.5$ & $36.3 \pm 1.9$ & $2.6 \pm 0.4$ & $4.8 \pm 0.8$ \\
\hline $\begin{array}{l}\text { 3-Control diabetic group } \\
1 \text { week }\end{array}$ & $101 \pm 8.9$ & $45.8 \pm 6.7$ & 46. $4 \pm 2.1$ & $2.8 \pm 0.9$ & $6.7 \pm 0.9$ \\
\hline After 12 week & $168.7 \pm 18$ & $74.8 \pm 4.6$ & $79.2 \pm 3.6$ & $3.04 \pm 0.6$ & $17.1 \pm 0.8$ \\
\hline $\begin{array}{l}\text { 4- ST diabetic group } \\
\text { 1week }\end{array}$ & $99.6 \pm 18$ & $48.5 \pm 6.6$ & $48.7 \pm 4.3$ & $2.7 \pm 0.5$ & $6.8 \pm 0.5$ \\
\hline After 12 week & $119.5 \pm 15.1^{*}$ & $57.2 \pm 1.4^{*}$ & $53.5 \pm 6.2^{*}$ & $2.5 \pm 0.9^{*}$ & $12.5 \pm 0.4^{*}$ \\
\hline
\end{tabular}

The data represent the mean \pm SD of 10 animals. ${ }^{*} P<0.05$ as compared with the corresponding value of the control diabetic group.

** Hg A1c: Glycosylated (or glycated) hemoglobin.

- International Units per Liter. following:-

The histochemical examination of the liver and kidneys showed the

\section{Periodic acid Schiff's (PAS) technique:-}

Liver: Examination of liver sections of control mice stained with periodic acid Schiff's (PAS) technique showed the abundance of glycogen in the form of purple granules and particles at one side of the cytoplasm leaving the other one almost devoid of such material in the hepatocytes. The nuclei of the hepatocytes gave negative PAS reaction indicating the absence of glycogen. The hepatocytes at the peripheral regions appeared markedly rich with glycogen particles than pericentral ones (Fig. 3-A and B). Also histochemical examination of liver sections of control ST extract group stained with PAS (Fig.3-C and D) revealed the same appearance of control group. The histochemical examination of liver of diabetic rats showed pericentral depletion of the PAS +ve materials (Fig. 3-E and F). In the liver of diabetic rats treated with ST extract, the polysaccharides appeared more or less like control with the exception of some cells (Fig. 3- G and H).

Kidney Examination of kidney sections of control mice stained with(PAS) technique showed the presence of polysaccharides in the form of PAS positive materials in the parietal and visceral walls of the Bowman's capsule, capillaries of the glomeruli, basement membrane of the proximal and distal convoluted tubules and the brush border of the proximal convoluted tubules (Fig. 4-A and B). Also histochemical examination of kidney sections of control ST extract group stained with PAS (Fig. 4-C and D) revealed the same appearance of control group. Light microscopy of the kidney sections of diabetic mice showed an increase in the PAS +ve material in the mesangial cell and matrix of the glomeruli. The basement membranes of the proximal and distal convoluted tubules appear thicker as compared with the control one (Fig. 4-E and F). Examination of kidneys of the diabetic mice treated with ST extract indicated that the polysaccharides of kidneys appeared more or less as control (Fig. 4-G and $\mathrm{H}$ ). 
Masson's Trichrome Stain (MTS) technique:

Liver: Examination of liver sections of control diabetic mice stained with Masson's Trichrome Stain (MTS) technique showed increase in the thickness of collagen fibers around the central vein in the form of light blue colour around the central vein (Fig. 5-E and F) as compared to normal control(Fig. 5-A and B) and ST control group (Fig, C and D). whereas, histochemical examination of liver of diabetic mice treated with ST extract showed remarked decrease in the collagen fibers and appeared more or less like control groups (Fig. 5- $\mathrm{G}$ and $\mathrm{H}$ ).

Kidney Examination of kidney sections of control mice stained with Masson's Trichrome Stain (MTS) technique showed the presence of normal thin layer of collagen fibers of (MAS) positive materials in the parietal and visceral walls of the Bowman's capsule, capillaries of the glomeruli, the basement membrane of the proximal and distal convoluted tubules (Fig 6- A and B). Examination of the kidney of control ST extract group showed the presence of normal collagen fibers of Masson trichrome (MAS)positive materials that appear more or less as control (Fig 6-C and D). While examination of kidney sections of control diabetic mice showed an increase in the MAS +ve material in the mesangial cell and matrix of the glomeruli. The basement membranes of the proximal and distal convoluted tubules appear thicker (Fig 6-E and F). Whereas histochemical examination of kidneys of diabetic mice that treated with ST extract showed remarked decrease in the collagen fibers and appeared more or less as control groups (Fig 6-G and H).

\section{DISCUSSION}

In this study we measured some components of the chemical content of the Syrian truffles (Tuber brumale vittadini) in terms of nutritional value as showen in table (1). This estimation revealed the proportions of protein, carbohydrate, fat, ash, fiber and most vitamins, minerals less than found in various types of truffles in Gulf, Egyptian, Saudi Arabia, Ghana and Iraq except for iron content was higher in the tubers studied compared to the content of desert truffles in. Also potassium, magnesium, calcium and zinc and vitamin E contents of ST was higher as compared in desert truffle in Saudi Arabia (Sawaya et al. ,1985; Al-Naama et al.,1988; Hashem and Al Obaid, 1996; Hussain and Al-Ruqaie,1999 and Afoakwa and Sefa-Dedeh, 2001). This indicated that, Syrian truffles have high nutritional value especially for diabetus, scince having low suger contents and high value of vitamins and minerals as shown.

Results revealed that ST extract ameliorates the fasting and postprandial blood glucose levels of alloxan diabetic mice were significantly reduced as compared with diabetic control results (Table 2). Also ST extract significantly lowered blood glucose level of diabetic mice in the glucose tolerance test from $410 \pm 19$. to $260 \pm 14 . .5 \mathrm{mg} / \mathrm{dl}$ after 120 minutes without any medications (Table 3 ) and significantly decreased $\mathrm{HbA} 1 \mathrm{c}$ ratio as compared with diabetic control results (Table 4). These results reveal the beneficial effect of ST in the diabetic mice and this agrees with previous studies with 
another hypoglycemic plant extract by Welihinda et al., 1982; Shibib et al., 1993; Sarkar et al.,1996; Ahmed et al., 1998; Blumenthal et al., 1998 and Yibchok-Anun et al.,2006.

Tuber brumale vittadini (ST) extract caused a significant decrease of AST, ALT, creatinine and cholesterol levels in the blood (Table 4). ST extract lowered cholesterol levels in alloxan diabetic mice. The extract may exerted rapid protective effects against lipid peroxidation by scavenging of free radicals there by reducing the risk of diabetic complications. Also this may be due to antioxidants of ST extract. Higher content of vitamin E and Zinc in ST extract may be decreased AST, ALT, creatinine and cholesterol levels in the blood as reported by several authors (Jain and Palmer, 1997; Jiatal and Grundy, 1998 and Zine et al., 2007)

Syrian truffle extract has been shown to significantly improve glucose tolerance and improved fasting blood glucose levels. This may be due to increase both glucose uptake by tissues and liver glycogen storage as demonstrated via histochemical investigations (Fig. 3). Taylor, et al., (1993) reported that insulin stimulates glycogen synthesis in the liver and skeletal muscle. After a meal, the secretion of insulin from pancreatic $\beta$ cells thus results in about $20 \%$ and $30 \%$ of the carbohydrate intake being stored in the form of glycogen in the liver and skeletal muscle, respectively. Defects in this process can therefore be a major contributor to postprandial hyperglycemia. Indeed, the glycogen contents of the liver and skeletal muscle are reduced in individuals with type 2 diabetes (Shulman, 1990 and Magnusson, et al., 1992). These findings support the use truffle extract in glycogenolytic versus gluconeogenic flux in hepatic glucose production, and they demonstrate that glycogenolysis inhibitors may be useful in the treatment of type 2 diabetes as shown previously by Martin, et al., (1998).

Type 2 diabetes is a metabolic disorder characterized by insulin resistance as well as a progressive deterioration of pancreatic $\beta$-cell mass and function. The hypoglycemic effect of Syrian truffle may be mediated through stimulating synthesis and / or release of insulin from the beta cells of Langerhans or due to regeneration of pancreatic islet cells. This agrees with the previous studies by (Wang et al., 1994). Syrian tuber may block the release of glucose in the blood stream and breaks down the barrier that prevents cells from using their own natural insulin and this anti-diabetic effect may be due to the increase in number of $\beta$ cells by the pancreas, thereby improving ability to produce and release insulin, or may increase the number and activity of insulin receptors. It has been shown by several studies that dimethylsulfide, 2-methylpropanal, 2-methylbutanal, 3 methylbutanal, 2methyl-1-propanol, 2-methyl-1-butanol and 3-methyl-1-butanol are most characteristic compounds of Tuber spp. (Talou, et al., 1990; Sunda, et al, 2002; Zarivi et al., 2003). Klandorf et al.,(1989) concluded that when Dimethyl sulfoxide accelerates the uptake of dietary diabetogens into the beta-cell Non-obese onset diabetic mice. Daniel and Habener (2002) reported that, Dimethyl sulfoxide (DMSO), the most characteristic compounds of Tuber spp., may involve redistribution of intracellular compartments or a direct molecular interaction with a downstream target of the glucagon-like peptide 1 (GLP-1) receptor signaling pathway in the $\beta$-cell. The authors showed that 
DMSO may use as a therapeutic treatment in type 2 diabetes. Buteau, (2008) concluded that, Glucagon-like peptide 1 (GLP-1), is a promising therapeutic agent in the treatment of diabetes. GLP-1 constitutes a novel class of anti-diabetes medications which address both the insulin secretion defect as well as the decline in $\beta$-cell mass.

In general, increased hepatic glucose production, plus decreased hepatic glycogen synthesis and glycolysis, are the major symptoms in type 2 diabetes that result in hyperglycemia, and these would seem to be the consequence of the low glucokinase activity and high glucose-6-phosphatase in a diabetic state (DeFronzo, 1988; Reaven, 1997 and Guignot \& Mithieux 1999).

Hepatic glucokinase is the most sensitive indicator of the glycolytic pathway in diabetes and its increase can increase the utilization of blood glucose for glycogen storage in the liver (lynedjian, et al., 1988). In the current study, supplementation of Syrian truffle extract may increase hepatic glucokinase. Also, hepatic glycogen reserves are important for whole-body glucose homeostasis and are markedly low in the diabetic state (Hornbrook, 1970; Migliorini, 1971 and Whitton \& Hems 1975). In the current study, the hepatic glycogen concentration was higher in the ST-diabetic group compared with the control diabetic group (Fig.3). The current results suggest Syrian truffles play important role in preventing the progression of hyperglycemia, partly by increasing hepatic glycolysis and glycogen concentration and/or by lowering hepatic gluconeogenesis. This in concordance with the report of (Jung, et al., 2004). Also, McGarry, (1992) explained that chronic insulin deficiency and insulin insensitivity are the major causes of the decreased hepatic glucose utilization and increased glucose production in several animal models of type 2 diabetes, e.g., mice, because insulin decreases the hepatic glucose output by activating glycogen synthesis and glycolysis, and by inhibiting gluconeogenesis.

Our results showed that oral administration of ST extract for 12 weeks decreased blood glucose level and prevents the onset of complications and also delays progression of complications in diabetes. The ST extract acts as an essential trigger for both liver and kidney to revert to their normal metabolic homeostasis i.e., ST extract possesses anti-diabetic, hepatic and renal protective effect in alloxan-induced diabetic mice. The liver and kidney exhibits numerous morphological and functional alterations during diabetes (Sochar,et al., 1985). Histochemical examination of liver of diabetic mice showed pericentral glycogen depletion (Fig. 3). Light microscopy of kidney sections of diabetic mice (Fig. 4) showed an increase in mesangial cell and matrix of glomeruli with increase in glycogen deposition and hyalinization of arterioles with thickened basement membranes of proximal and distal convoluted tubules. During diabetes liver shows enhanced catabolic processes such as glycogenolysis, lipolysis and proteolysis, which is the outcome of lack of insulin and/or cellular glucose in liver cells. 

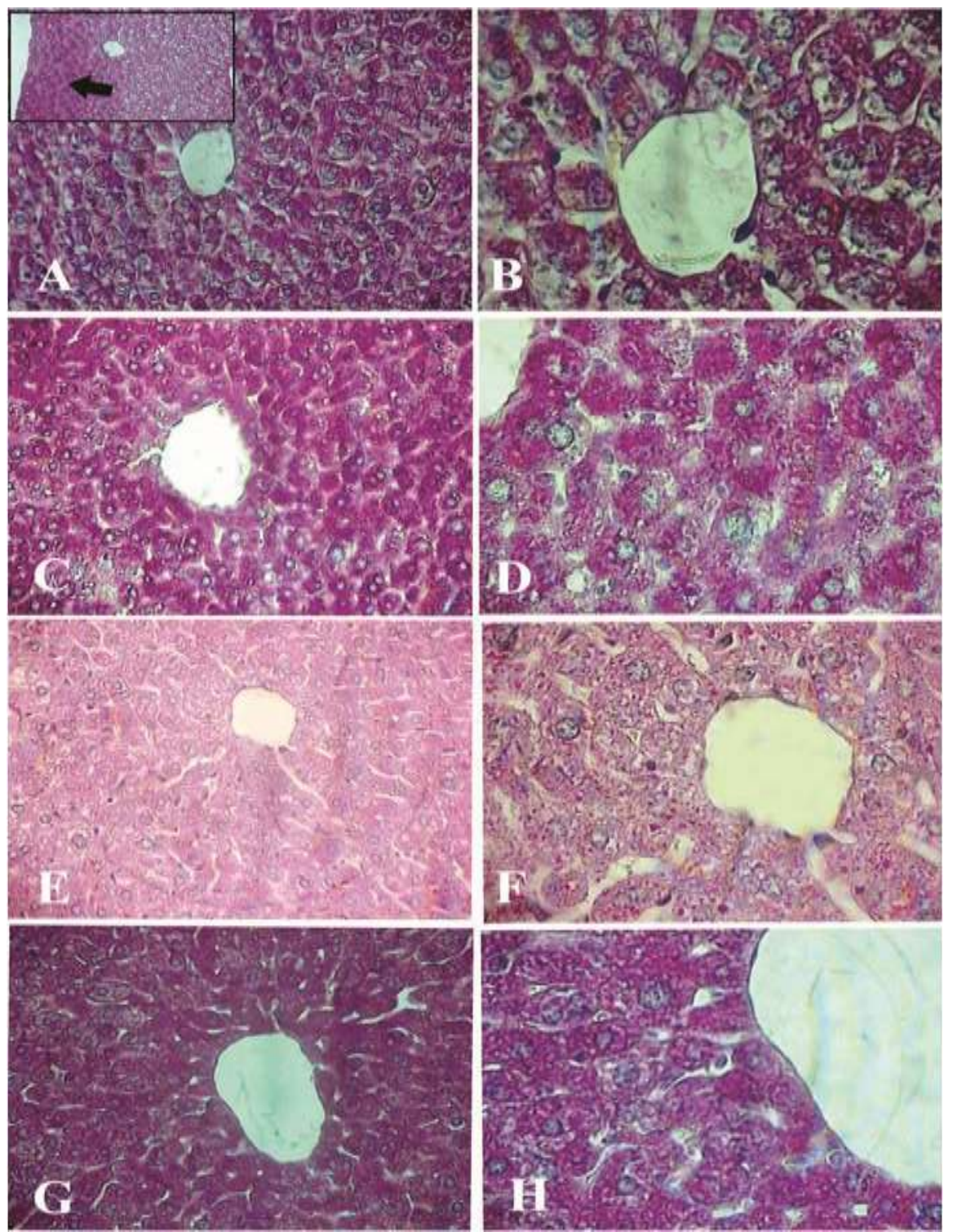

Figure (3): Photographs of sections of the liver show the polysaccharides (A and $B$ ): control mice showing the normal distribution, the glycogen particles accumulated at one side of the cytoplasm of hepatocytes leaving the other side almost devoid of such material. (C and D): liver of control mice treated with ST extract shows the polysaccharides appear more or less like control ( $E$ and $F$ ): liver of diabetic mice showed pericentral depletion of the PAS +ve materials, ( $G$ and $H$ ): liver of diabetic mice treated with ST extract shows the polysaccharides appear more or less like control with the exception of some cells. (PAS $A, C, E$ and $G, 150 X$ whereas B,D,F and H, $400 X$ ). 


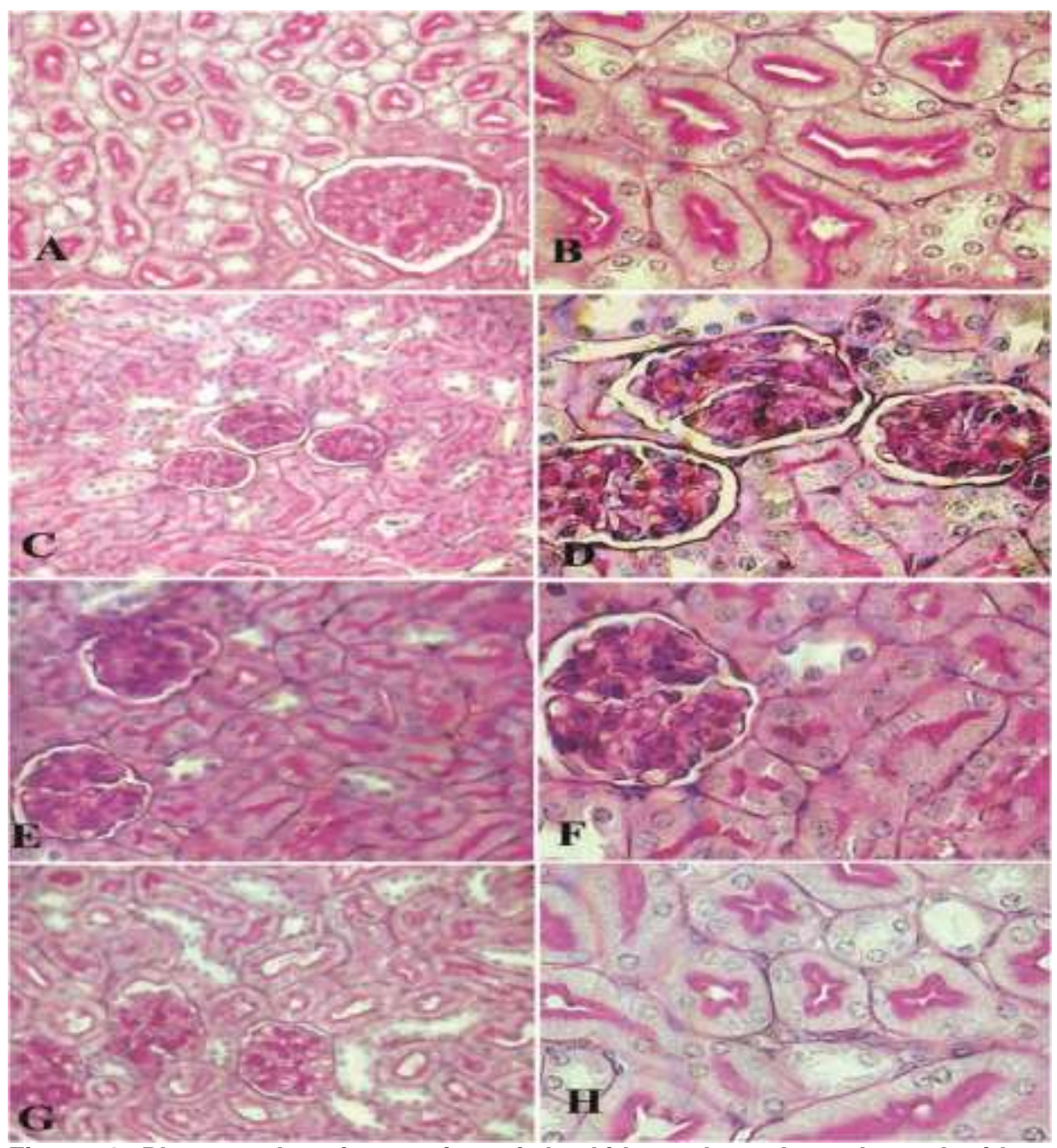

Figure 4: Photographs of a section of the kidney show the polysaccharides Aand B): Kidney of control mice showed the presence of polysaccharides in the form of PAS positive materials in the parietal and visceral walls of the Bowman's capsule, capillaries of the glomeruli, the basement membrane of the proximal and distal convoluted tubules and the brush border of the proximal convoluted tubules, ,(C and D) Kidney of control mice treated with ST extract showed the presence of normal polysaccharides in the form of PAS positive materials that appear more or less as control ,(E and F) kidney of diabetic mice show an increase in the PAS +ve material in the mesangial cell and matrix of the glomeruli. The basement membranes of the proximal and distal convoluted tubules appear thicker, and ( $G$ and F): kidneys of the diabetic mice that treated with ST extract show the polysaccharides that appear more or less as control. (PAS A,C,E and $G, X 150$ whearase $B, D, F$ and $H, 400 X$ ). 
There is, however, an increase in glucose over-utilization and subsequent enhancement in glycogen synthesis, lipogenesis and protein synthesis (Meyer, et al., 1998). These changes may lead to serious microvascular renal complications, which involve a series of metabolic changes in the pathogenesis of diabetic nephropathy (Raju,et al.,2001). Our results indicated that treatment of diabetic mice with ST extract prevented the alteration in liver and kidney weight and pathology with the return to their normal texture in agreement with previous studies (Raju,et al.,2001; Devi, et al.,2003and Neveen, et al.,2007). In diabetes, reactive oxygen species, several immunomodulatory factors and chronic inflammatory states can contribute to insulin resistance and liver injury. Recently, several reports have at least partially elucidated the cellular and molecular mechanisms underlying this inflammatory response (Cohn and Roth, 1996).

The kidney exhibits a characteristic pattern of changes during diabetes (Sharma, et al., 2003). The increase in oxygen free radicals in diabetes could be primarily due to increase in blood glucose levels, which upon autoxidation generate free radicals and secondarily due to the effects of the diabetogenic agent (streptozotocin or alloxan)( Szkudelski, 2001).

Syrian truffle extract decreased collagen fibers in liver and kidney tissues of diabetic mice (Fig 5 and 6) as compared with the control group. Collagen synthesis, in particular, is critical to the development of strength in a healing wound site. A healing progress, the number of proliferating fibroblasts and new vessels decreases; however, the fibroblasts progressively assume a more synthetic phenotype, and hence there is increased deposition of extracellular matrix ECM. Collagen synthesis by fibroblasts begins early in a healing wound. Many of the same growth factors that regulate fibroblasts proliferation also participate in stimulating ECM synthesis. Collagen synthesis, for example, is induced by a number of molecules, including growth factors and secreted by leukocytes and fibroblasts. Net collagen accumulation, however, depends not only on increased synthesis but also on diminished collagen degradation. Ultimately, the granulation tissue scaffolding evolves into a scare composed of largely inactive, spindle-shaped fibroblasts, dense collagen, fragments of elastic tissues, and other ECM components (Vinay, et al., 1997).

Prockop and Kivirikko (1995) explained fibrosis or fibroplasias in two steps: (1) emigration and proliferation of fibroblasts in the site of injury, and (2) deposition of ECM by these cells. The recruitment and stimulation of fibroblasts is driven by the various growth factors include activated endothelium, but perhaps more importantly, they also include a variety of inflammatory cells. Macrophages, for example, are important cellular constituents of granulation tissue, responsible for clearing extracellular debris, fibrin, and other foreign matter at the site of injury and therefore promote fibroblast migration and proliferation. If the appropriate chemotactic stimuli are present, lymphocytes may also be present, and mast cells are increased in number; each of these can contribute directly or indirectly to fibroblast proliferation and activation. 


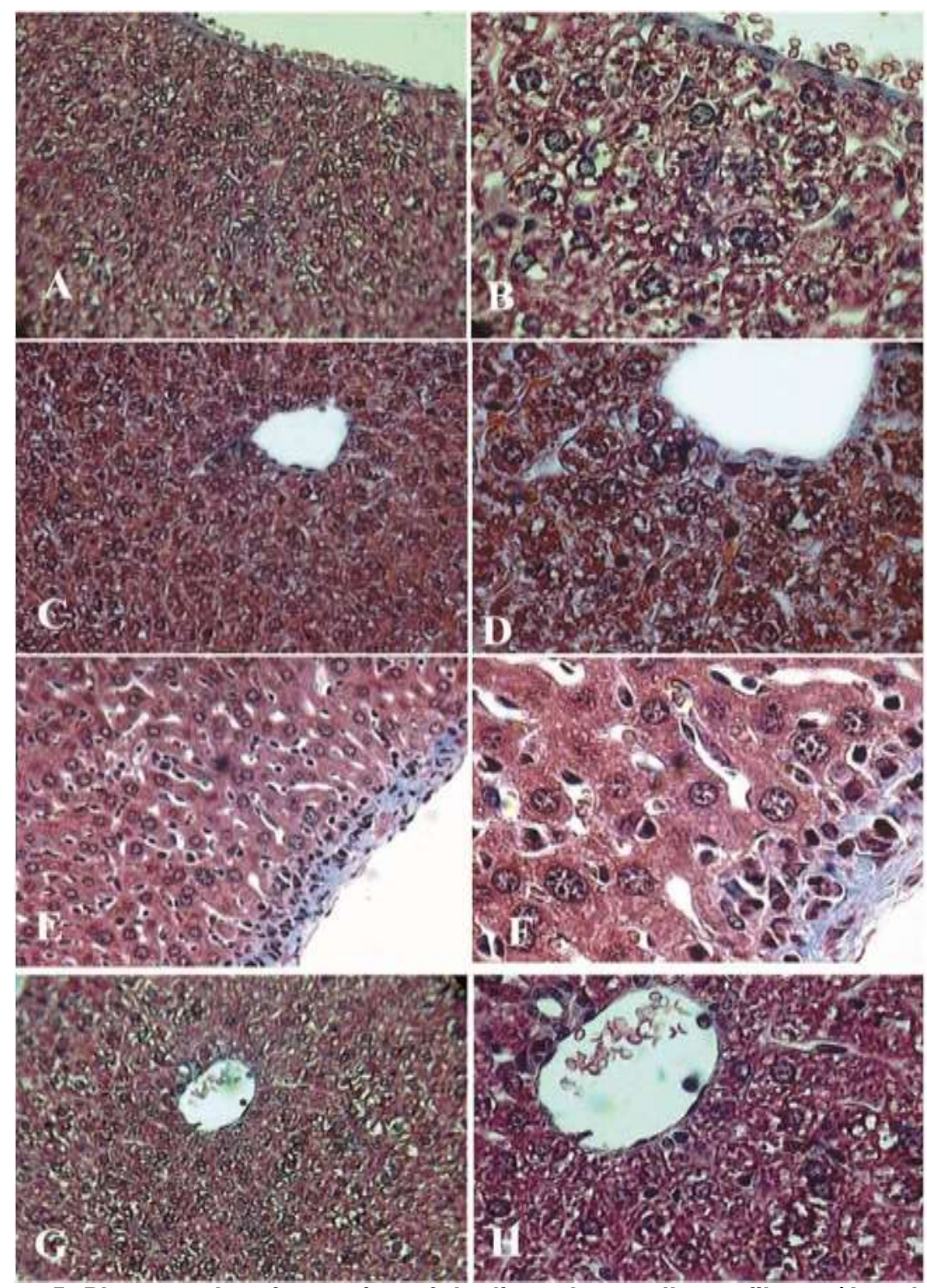

Figure 5: Photographs of a section of the liver show collagen fibers: (A and B): liver of control mice showed the presence of normal collagen fibers of Masson trichrome (MAS) positive materials, (C and D): liver of control mice treated with ST extract showed the presence of normal collagen fibers of Masson trichrome (MAS)positive materials that appear more or less as control, (E and $F)$ liver of diabetic mice show an increase in the MAS +ve material in the central vein, and ( $G$ and $H$ ) : liver of the diabetic mice that treated with ST extract show the collagen fibers that appear more or less as control (MAS A,C,E and G,X150 whearase B,D,F and $\mathrm{H}, 400 \mathrm{X}$ ). 

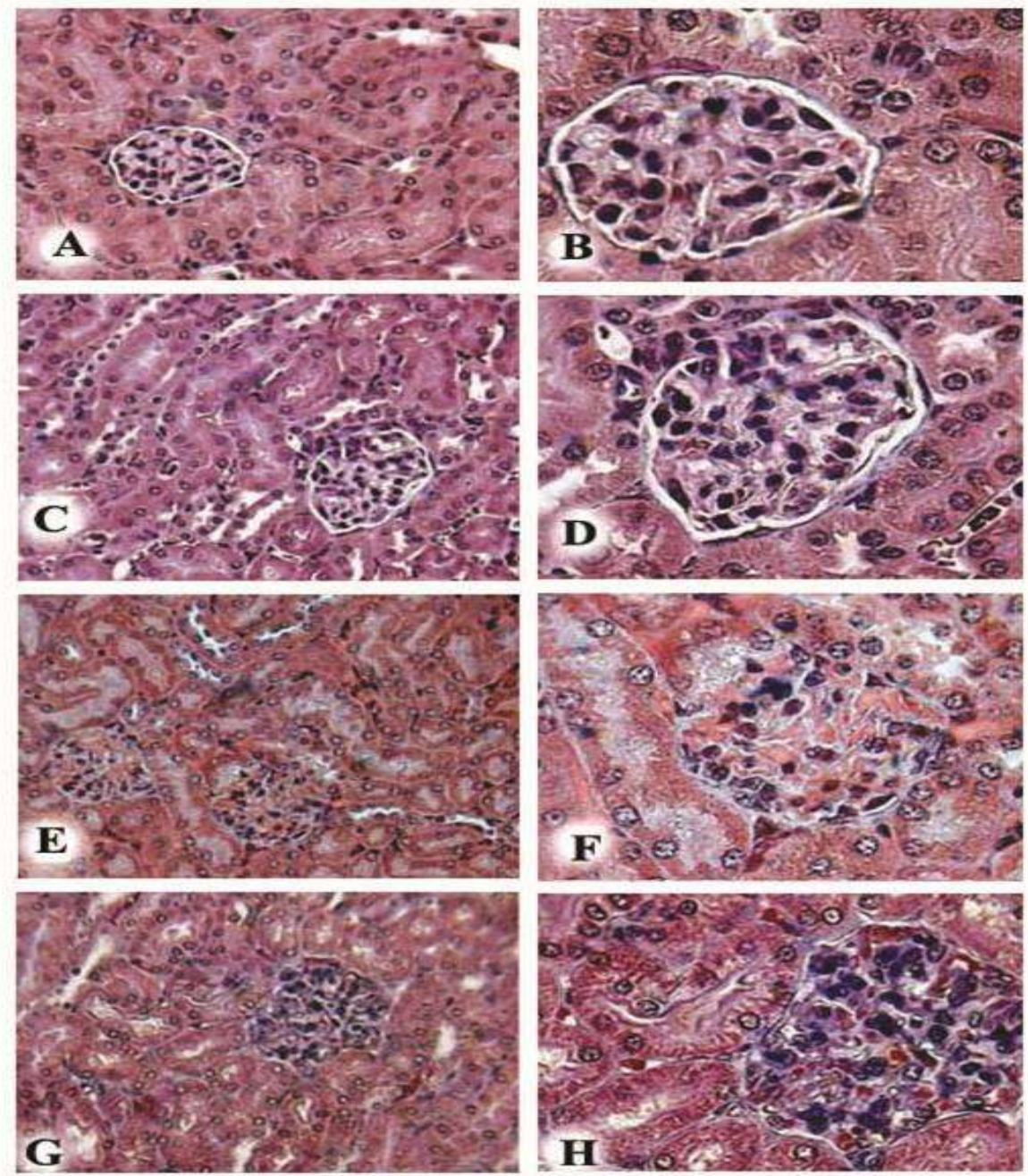

Figure 6: Photographs of a section of the kidney show collagen fibers: (A and B): Kidney of control mice showed the presence of normal collagen fibers of Masson trichrome (MAS)positive materials in the parietal and visceral walls of the Bowman's capsule, capillaries of the glomeruli, the basement membrane of the proximal and distal convoluted tubules ,(C and D) Kidney of control mice treated with ST extract showed the presence of normal collagen fibers of Masson trichrome (MAS)positive materials that appear more or less as control ,(E and $F)$ kidney of diabetic mice show an increase in the MAS +ve material in the mesangial cell and matrix of the glomeruli. The basement membranes of the proximal and distal convoluted tubules appear thicker, and $\mathrm{G}$ and $\mathrm{H}$ : kidneys of the diabetic mice that treated with ST extract show the collagen fibers that appear more or less as control (MAS A,C,E and $\mathrm{G}, \mathrm{X} 150$ whearase B,D,F and $\mathrm{H}, 400 \mathrm{X}$ 
The conclusions of the present study are summarized as follows: - (1) one or more constituents of ST may be responsible for reducing blood glucose level in the alloxan diabetic mice.(2) the hypoglycemic effect of ST may be related to the action of ST in reducing the intestinal glucose absorption thereby helping to control the increase in postprandial blood sugar levels. (3) ST significantly improved the performance of alloxan diabetic mice in the glucose tolerance test and hemoglobin A1c ratio (4) ST extract caused a significant decrease AST, ALT, creatinine and cholesterol levels in the blood of alloxan diabetic group and (5) ST extract suppressing the oxidative stress together with converting liver and kidney pathology caused by diabetes to normal pattern.

These findings revealed that Syrian truffle may have a potential benefit in the treatment of diabetics and plays a role in the management of diabetes and reducing the risk of diabetic complications.

\section{Acknowledgment}

We thank to Deanship of Scientific Research, King Faisal University, Faculty of Agriculture and Food Sciences, Saudi Arabia for supporting this research. Thanks also to Dr. Mayada Al Hassan for her assistance in bringing the Syrian truffles for this research and all those who contributed to the achievement of this research.

\section{REFERENCES}

ADA, The American Diabetes Association (2008): Standards of medical care in diabetes. Clinical Practice Recommendations. Diabetes Care, 31(Suppl 1): S12-S54.

Afoakwa , E. O. and Sefa-Dedeh , S. (2001): Chemical composition and quality changes occurring in Dioscorea dumetorum pax tuber after harvest . Food Chemistry . $75: 85-91$.

Ahmed I, Adeghate E and Sharma AK, (1998): "Effects of Momordica charantia fruit juice on islet morphology in the pancreas of the streptozotocin-diabetic rat." Diabetes Res. Clin. Pratt.;40:145-151.

Alercon-Aguilar F.J.; Jimenez-Estrada M.; Reyes-Chilpa, R. and RomanRamos, R.Z. (2000): Hypoglycemic effect of extracts and fractions from Psacalcium decompositum in healthy and alloxan-diabetic mice. J. Ethnopharmacol. , 72(1-2): 21-27.

Al-Naama , M.M. , Ewaze , J.O. and Nema , J.H. (1988): Chemical constituents of Iraqi truffles. Iraqi Journal of Agriculture Sciences . 6 ( 2) : $51-56$.

Ammarellou, A. (2007): Protein profile analysis of desert truffle ( Terfezia claveryi Chatin ) . J F Agri \& Envi . 5 (2) : 62 -64 .

AOAC,(1995): Official method of analysis,16th, Association of Analytical Chemists.Washinton,D.C., USA.

Ayyanar, M. ; Sankarasivaraman, K. and Ignacimuthu, S. (2008): Traditional Herbal Medicines Used for the Treatment of Diabetes among Two Major Tribal Groups in South Tamil Nadu India. Ethnobotanical Leaflets, 12: 276-280. 
Bancroft, J.D. and Stevens, A. (1990): "Theory and Practice of Histological Technique", 3rd edition, Churchill Livingstone, New York.

Bastaki, Salim.(2005): Diabetes mellitus and its treatment. Int. J. Diabet. Metab., 13:111-134.

Blumenthal, M.; Busse, W.R. ; Goldberg, A.; Gruenwald, J.; Hall, T.; Riggins, C. W. and Rister, R. S. Eds. (1998): The Complete German Commission E Monographs: Therapeutic Guide to Herbal Medicines. Boston, MA: Integrative Medicine Communications, 130.

Buteau, J. (2008): GLP-1 receptor signaling: effects on pancreatic $\beta$-cell proliferation and survival Signalisation, Diabetes \& Metabolism,Vol,34(2), P: S73-S77

Cohn, R.M. and K.S. Roth, (1996): Biochemistry and disease. Williams and Wilkins Publishers, Baltimore, Lipid and lipoprotein metabolism, pp: 280.

Daniel M. Kemp and Joel F. Habener (2002): Synergistic effect of dimethyl sulfoxide on glucagon-like peptide 1 (GLP-1)-stimulated insulin secretion and gene transcription in INS-1 cells: characterization and implications Biochemical Pharmacology Vol. 64, Issue 4, 15 2002, Pages 689-697.

DeFronzo, R. A. (1988): The triumvirate: beta-cell, muscle, liver. Acollusion responsible for type 2 diabetes. Diabetes 37:667-687.

Devi, B.A., N. Kamalakkannan and P.S. Prince (2003): Supplementation of fenugreek leaves to diabetic rats. Effect on carbohydrate metabolic enzymes in diabetic liver and kidney. Phytother Res., 17(10): 1231-3.

Diaz, P., Ibanez, E., Senorans, F.J. and Reglero, G., (2003): Truffle aroma characterization by headspace solid-phase microextraction. J. Chromatogr. A 1017, 207-214.

Diaz, P., Senorans, F.J., Reglero, G. and Ibanez, E., (2002): Truffle aroma analysis by headspace solid phase microextraction. J Agric Food Chem 50:6468-72.

Fontana A and Giovannetti G (1979): Simbiosi micorrizica fra Cistus incanus L. spp. incanus e Tuber melanosporum Vitt. Allionia 23: 5-11.

Fischbach FT. and Dunning MB. (2004): Manual of Laboratory and Diagnostic Tests. 7th ed. Philadelphia: Lippincott Williams and Wilkins.

Flower, J. and Cohen, L. (1997): Practical statistics for field biology. John Wiley \&Sons, New York.

Gao, J.-M., Hu, L. and Liu and J.-K., (2001): A novel sterol from Chinese truffles Tuber indicum. Steroid 66, 771-775.

Guignot, L. and Mithieux, G. (1999): Mechanisms by which insulin, associated or not with glucose, may inhibit hepatic glucose production in the rat. Am. J. Physiol. 277:E984-E989.

Hall,I. and Yun, W.(2002): Ectomycorrhizal fungi which edible fruiting bodies: Tuber melanosporum. Edible mycorrhizal mushroomes and their cultivation.Proceedings of the second International conference on edible mycorrhizal mushrooms, CD-ROM(Hall, I.R.,Wang, Y., Zambonelli, A. \& Danell, E., eds). New Zealand Institute for Crop \&Food Research limited, Christchurch. 
Harley JL and Smith SE (1983): Mycorrhizal Symbiosis, Academic Press, London.

Harki, E., Klaebe, A., Talou, T. and Dargent, R., (1996): Identification and quantification of Tuber melanosporum. Vitt. Sterols Steroids 61, 609612.

Hashem , A. R. and Al-Obaid, A. M. (1996): Mineral composition of soil and wild desert truffles in Saudi Arabia. J. King Saud Univ. , Vol 8 , Science (1) : $5-10$.

Hawksworth, D.L., Kirk, P.M., Sutton, B.C. and Pegler, D.N., (1995:) Truffle: Dictionary of the Fungi. University Press, Cambridge, pp. 467-469.

Hem, A., Smith, AJ. and Solberg, P. (1998): Saphenous vein puncture for blood sampling of the mouse, rat, hamster, gerbil, guineapig, ferret and mink. Lab. Anim., 32: 364-368.

Hornbrook, K. R. (1970): Synthesis of liver glycogen in starved alloxan diabetic rats. Diabetes 19:916-923.

Hussain , Gh. and Al-Ruqaie , I. M. (1999): Occurrence, chemical composition and nutritional value of truffles : an overview . Pakistan Journal of Biological Sciences. 2 (2) : 510- 514.

lynedjian, P. B., Gjinovci, A. and Renold, A. E. (1988): Stimulation by insulin of glucokinase gene transcription in liver of diabetic rats. J. Biol. Chem. 263:740-744.

James, R., Tyler, C. and Henrikson, D. (1988): An evaluation of the accuracy of the Reflotron system in the field. Med. J. Aust., 149(3):130-131.

Jain S.K, and Palmer M. (1997): The effect of oxygen radical metabolites and vitamin $\mathrm{E}$ on glycosylation of proteins. Free Radic Biol Med; 22: 593.

Jeppsson, J.O.; Kobold, U.; Barr, J.; Finke, A.; Hoelzel, W.; Hoshino, T.; Miedema, K.; Mosca, A. ; Mauri, P.; Paroni, R.; Thienpont, L.; Umemoto, M. and Weykamp, C.( 2002): Approved IFCC reference method for the measurement of $\mathrm{HbA} 1 \mathrm{c}$ in human blood. Clin. Chem. Lab. Med.,40(1):78-89.

Jiatal I and Grundy SM. (1998): Effect of combined supplementation with alpha-tocopherol, ascorbate, and beta-carotene on low-densitylipoprotein oxidation. Circulation; 88: 2780.

Jung, U. J.; Mi-Kyung; L. , Kyu-Shik J. and Myung-Sook, C. (2004): The Hypoglycemic Effects of Hesperidin and Naringin Are Partly Mediated by Hepatic Glucose-Regulating Enzymes in C57BL/KsJ-db/db Mice J. Nutr. 134:2499-2503

Klandorf, H.; Chirra A.R; DeGruccio, A. and Girman, D.J. (1989): Dimethyl sulfoxide modulation of diabetes onset in NOD mice. Diabetes ;38(2):194-7.

Larsen, M.L.; Hørder, M. and Mogensen, E.F. (1990): Effect of long-term monitoring of glycosylated hemoglobin levels in insulin-dependent diabetes mellitus . N. Engl. J. Med., 323 (15): 1021-5.

Mandeel , Q. A. and Al-laith , A. A. (2007): Ethnomycological aspects of desert truffle among native Bahraini and non-Bahraini peoples of Kingdom of Bahrain . Journal Ethnopharmacology . 110 : 118-129. 
Martin, W.H.; Hoover, D. J.; Sandra, J. A., Ingrid, A. S. ; McPherson, R. K.; Dennis, E. D. ; Stevenson, R. W.; Eugene, J. B. ; and Judith, L. T.(1998): Discovery of a human liver glycogen phosphorylase inhibitor that lowers blood glucose in vivo. Natl Acad Sci; 17; 95(4): 1776-1781

McGarry, J. D. (1992): What if Minkowski had been ageusic? An alternative angle on diabetes. Science 258:766-770.

Magnusson I, Rothman DL, Katz LD, Shulman RG and Shulman GI. (1992): Increased rate of gluconeogenesis in type II diabetes mellitus. A 13C nuclear magnetic resonance study. J. Clin. Invest. ; 90:1323-1327.

Menotta, M., Gioacchini, A.M., Amicucci, A., Buffalini, M., Sisti, D. and Stocchi, V. (2004): Headspace solid-phase microextraction with gas chromatography and mass spectrometry in the investigation of volatile organic compounds in an ectomycorrhizae synthesis system. Rapid Commun. Mass Spectrom. 18, 206-210.

Meyer, C., M. Stumvoll, V. Nadkarni, J. Dostou, A. Mitrakou and J. Gerich, (1998): Abnormal renal and hepatic glucose metabolism in type 2 diabetes mellitus; J. Clin. Invest., 102: 619-624.

Migliorini, R. H. (1971): Early changes in the levels of liver glycolytic enzymes after total pancreatectomy in the rat. Biochim. Biophys. Acta 244:125128.

Nelson W. and Halberg F. (1986): Meal-timing, circadian rhythms and life span of mice. J. Nutr. 116: $2244-2253$.

Neveen H. A.; Khalil, M.Y. ; Hussein, J.S.; Oraby, F.S.H. and Hussein A.R. F. (2007): Antidiabetic Effects of Fenugreek Alkaliod Extract in Streptozotocin Induced Hyperglycemic Rats Journal of Applied Sciences Research, 3(10): 1073-1083.

O'Donnell K, Cigelnik E, Weber NS and Trappe JM (1997): Philogenetic relationships among ascomycetous truffles and the true and false morels inferred from $18 \mathrm{~S}$ and $28 \mathrm{~S}$ ribosomal DNA sequence analysis. Mycologia 89(1):48-65

Olivier, J.M., Savignac, J.C. and Sourzat, P. (1996): Truffe et trufficulture. Editions Fanlac, Périgueux.

Pearse ,A. G. E. (1985): Histochemistry Theorical and Applied. 4th Ed.Churchill Livingstoes, London.

Phillips, S.; Wyndham, L.; Shaw, J. and Walker, SF.(1988): How accurately does the Reflotron dry-chemistry system measure plasma total cholesterol levels when used a community-screening device. Med. J. Aust., 149(3):122-125.

Prockop D. J. and Kivirikko K.L.(1995): Collagens:molecular Biology, diseases and potentials for therapy. Annu. Rev. Biochem.64:304.

Raju, J., D. Gupta, A.R. Rao, P.K. Yadava and N.Z. Baquer (2001): Trigonella foenum-graecum (fenugreek) seed powder improves glucose homeostasis in alloxan diabetic rat tissues by reversing the altered glycolytic, gluconeogenic and lipogenic enzymes; Mol. Cell. Biochem., 224: 45-51.

Reaven, G. M. (1997): Role of insulin resistance in human disease. Nutrition 13:64-66. 
Sarkar S, Pranava M and Marita R. (1996): "Demonstration of the hypoglycemic action of Momordica charantia in a validated animal model of diabetes." Pharmacol Res;33:1-4.

Sawaya , W.N. , Al-Shalhat, A. ,Al-Sogir , A. and Al-Mohammad, M. (1985): Chemical composition and nutritive values of truffles of Saudi Arabia . Journal of Food Science . 50 ( 2 ) : $450-453$.

Sharma, K., P. McCue and S.R. Dunn, (2003): Diabetic kidney disease in the $\mathrm{db} / \mathrm{db}$ mouse. Am J Physiol., 28: F1138-F1144.

Schwartz, J. G. (1995): The role of glycohemoglobin and other proteins in diabetic management. Diab. Rev., 3:269-287.

Shenoy, C. (2000): Hypoglycemic activity of bio-tea in mice. Indian J. Exp. Boil., 38(3): 276-279.

Shibib BA, Khan LA and Rahman R. (1993): "Hypoglycemic activity of Coccinia indica and Momordica charantia in diabetic rats: depression of the hepatic gluconeogenic enzymes glucose-6-phosphatase and fructose-1,6 bisphosphatase and elevation of both liver and red-cell shunt enzyme glucose-6-phosphate dehydrogenase." Biochem J 1993;292:267-270.

Shulman Gl. (1990): Quantitation of muscle glycogen synthesis in normal subjects and subjects with non-insulin-dependent diabetes by $13 \mathrm{C}$ nuclear magnetic resonance spectroscopy. N. Engl. J. Med.; 322:223228.

Sochar, M., N.Z. Baquer and P. Mclean, (1985): Glucose under utilization in diabetes. Comparative studies on the changes in the activities of enzymes of glucose metabolism in rat kidney and liver. Mol Physiol., 7: 51-68.

Srividya, K. and Shailendra, B. (2008): Diabetes Mellitus: Considerations for Dentistry. J. Am. Dent. Assoc., 139:8S-18S.

Sunda, W., Kieber, D. J., Kiene, R. P. and Huntsman, S. (2002): An antioxidant function for DMSP and DMS in marine algae. Nature, 418(6895), 317-320.

Szkudelski, T., (2001): The mechanism of alloxan and streptozotocin action in $\mathrm{b}$ cells of the rat pancreas. Physiol. Res., 50: 536-546

Takeshi, M. ; Michiyo, S.; Hidenori, T. ; Yuko, O and Cherian, G. (1998): Metallothionein does not protect mouse endocrine cells from damage induced by alloxan injection. Toxicology, 132: 33-41.

Talou, T., Gaset, A., Delmas, M., Kulifaj, M., and Montant, C. (1990): Dimethyl sulphide: the secret for black truffle hunting by animals. Mycological Research, 94(2), 277-278.

Taylor R, Price TB, Katz LD, Shulman RG and Shulman Gl. (1993): Direct measurement of change in muscle glycogen concentration after a mixed meal in normal subjects. Am. J. Physiol. 265(2 Pt 1):E224-9

Thevarajah, M. ; Nadzimah, M.N. and Chew, Y. (2009): Interference of hemoglobinA1c (HbA1c) detection using ion-exchange high performance liquid chromatography (HPLC) method by clinically silent hemoglobin variant in University Malaya Medical Centre (UMMC) - A case report. Clin. Biochem.,42 (4):430-434. 
Wadaan, M. (2006): Blood chemistry of domestic rabbits exposed to an oxidative hair dye. Intl. J. Pharmacol.,2(4):431-434.

Wang, R.; Bonwens, L. and Klo"ppel, G. (1994): Beta cell proliferation in normal and streptozotocin-treated newborn rats: site, dynamics and capacity. Diabeto., 37 1088-1096.

Welihinda, J.; Arvidson, G.; Gylfe, E.; Hellman, B. and Karlesson, E. (1982): The insulin releasing activity of the tropical plant Momordica charantia. Acta. Biol. Med. Germ., 41:1229-1240.

Whitton, P. D. and Hems, D. A. (1975): Glycogen synthesis in the perfused liver of streptozotocin-diabetic rats. Biochem. J. 150:153-165.

Wolfensohn, S. and Lloyd, M. (1994): Handbook of Laboratory Animal Management and Welfare. Oxford: Oxford University Press.

Vinay K., Ramizi S. C. and Staney L. R.(1997): Basic Pathology, 6th ed.,W.B. Saunders Company, New York, USA.

Yibchok-Anun S.; Adisakwattana S. and Yao CY.(2006): "Slow acting protein extract from fruit pulp of Momordica charantia with insulin secretagogue and insulinomimetic activities." Biol. Pharm. Bull.;29:1126-1131.

Zarivi, O., Bonfigli, A., Cesare, P., Amicarelli, F., Pacioni, G., and Miranda, M. (2003): Truffle thio-flavours reversibly inhibit truffle tyrosinase. FEMS Microbiology Letters, 220, 81-88.

Zeppa, S., Gioacchini, A.M., Guidi, C., Guescini, M., Pierleoni, R., Zambonelli, A. and Stocchi, V., (2004): Determination of specific volatile organic compounds synthesised during Tuber borchii fruit body development by solid-phase microextraction and gas chromatography/mass spectrometry. Rapid Commun. Mass Spectrom. 18, 199-205.

Zine Kechrid, EL-Hadjla Derai and Naima Layachi(2007): The beneficial effect of vitamin $E$ supplementation on zinc status, carbohydrate metabolism, transaminases and alkaline phosphatase activities in alloxan-diabetic rats fed on zinc deficiency diet Int $\mathrm{J}$ Diabetes \& Metabolism 15: 46-50

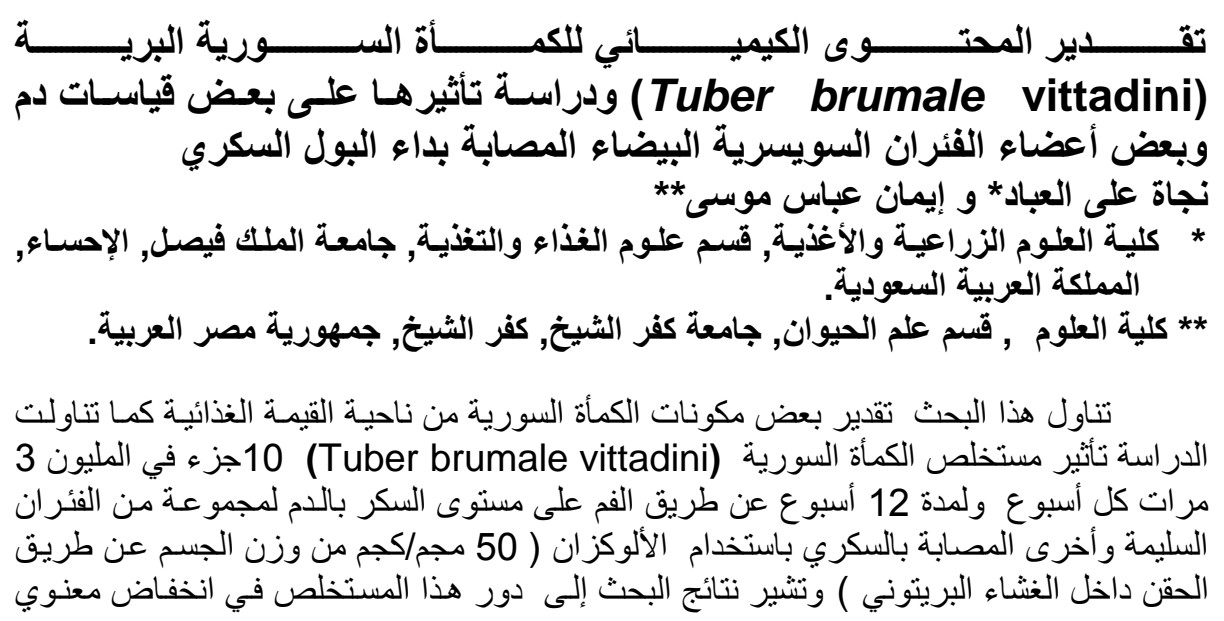




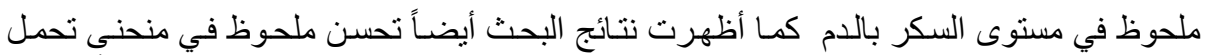

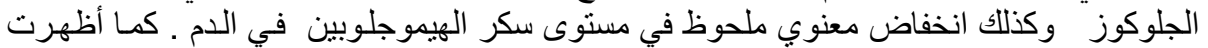

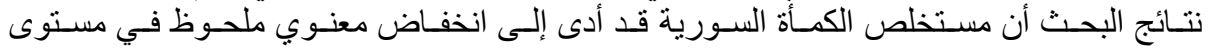

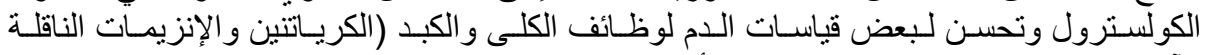

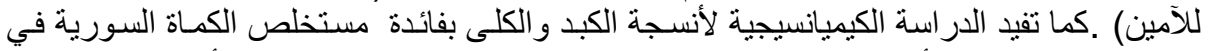

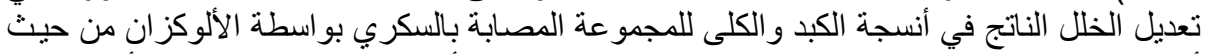

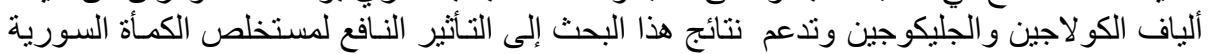

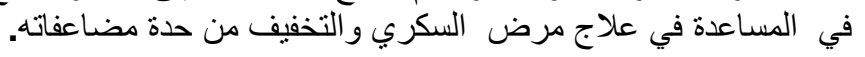

كلية الزراعة - جامعة المنصورة قام بتحكيم البحث كلية الزراعة - جامعة كفر الثيخ

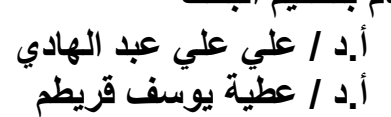

